\title{
A STUDY ON NPAS OF SELECTED PRIVATE \& PUBLIC SECTOR BANKS IN INDIA
}

\author{
Jayraj Javheri \\ Assistant Professor \\ Department of MBA \\ Sanjivani College of Engineering \\ Kopargaon-423 603, India \\ E-mail: jayrajjavheri@gmail.com \\ iD https://orcid.org/0000-0001-7868-6442 \\ Dr. Ravindra Gawali \\ Associate Professor \\ Department of MBA \\ Amrutvahini Institute of Management and Business Administration \\ Sangamner-422 605, India \\ E-mail: ravindra_gawali@ rediffmail.com \\ https://orcid.org/0000-0001-5409-3319
}

Received: December 08, 2021 Accepted: January 31, 2022 Online Published: February 13, 2022

DOI: $10.46281 / \mathrm{ijfb.v9i1.1610}$

URL: https://doi.org/10.46281/ijfb.v9i1.1610

\begin{abstract}
Banks play a very important role in any Financial System. It is the backbone of the Indian Financial System. The Rising NPA's of the Banks in India for the last 5 years has really posed a threat to the Indian financial system. Recently Standard \& Poor Global Rating agency has expected the NPA's of Indian banks to remain elevated at $11.5 \%$. NPA helps to measure the Performance of any bank. It is quite evident that the Recent Covid Pandemic has badly hit not only India but the entire world to a greater extent. The Public and Private sector banks in India both have been adversely affected by the Rising NPA. Through this research, it has been observed that Public sector banks are more adversely affected than Private sector banks. My Study Focus on the Trend \& Differences in the Non-Performing Assets of the Selected Indian Public and Private Sector Banks.
\end{abstract}

Keywords: NPA, Finance, Banks, Rating, Financial System.

JEL Classification Codes: E, G.

\section{INTRODUCTION}

The Indian Banking sector plays a very important role in the Indian Financial system. It acts as a link between lender and borrower. Banking in India has played a very important role to develop the saving habits among the masses. It helped to channelize the savings of the people into investment. In the past three decades Indian banking has outperformed and helped to develop the financial system in the country. Nevertheless Indian banking system has witnessed many revolutionary changes, for e.g. Nationalization of 14 major Private Banks in the year 1969. The Banking sector in India currently consist 
of Public sector Banks, Private sector Banks \& Foreign banks. In any Economy Banks plays a very major role in developing the financial system. Failure of banks reflects the failure of economy \& it has many adverse impact across the sectors. Strong and Healthy financial system increase the confidence in the economy and thus help to further increase investment and GDP of the country. In the last 5 years Indian banks are witnessing the Increase in number of NPAs. A high level of NPAs impact the liquidity \& Profitability of bank (Das \& Uppal, 2021). Credit creation by banks also get hampered due to the Rising NPAs. Continuity in Increased NPAs adversely impacts the economy, whereby the confidence in economy is lost and investment starts decreasing which in turn affects GDP of the economy. It has been found that NPA of Public sector bank is higher than private sector bank (Joseph \& Prakash, 2014; Miyan, 2017). Rise in NPA levels of Banks have also impacted their profitability (Wadhwa, 2020). Despite of different mechanism introduced by Government of India for the Quick Debt recovery such as Debt Recovery Tribunals throughout the country but this Debt Recovery Tribunal performance has been unsatisfactory from the evidence that the level of NPA has increased despite of Debt Recovery Tribunals (Alamelumangai \& Sudha, 2019). A Revolutionary change was bought in banking sector by Bringing the Sarfaesi Act, 2002 as a tool to expedite the loan recovery process for the Indian banks. The performance of sarfaesi act, 2002 has been far more satisfactory than DRTs in Loan recovery Process. To overcome the shortcomings of the DRTs and Sarfaesi act, 2002, Insolvency Bankruptcy Code was passed in the year 2016 to overcome the NPA Problem of the Indian banking sector and give the time bound solution for the NPA Recovery process.

IBC saves the banking system from the clutches of willful defaulters and make the promoters understood that they can no longer swindle the banks.

The performance of IBC during the last four years has been excellent in institutionalizing a mechanism for faster implementation of insolvency laws in India, much more can be done in the coming years (Kumara, 2018).

Non-Performing Assets (As per the RBI Announcement)

A non-performing asset (NPA) is a loan or advance for which the principal or interest payment remained overdue for a period of 90 days.

Classification of NPAs (As per the RBI Guidelines)

- Substandard Assets: - An Asset which remains as NPA for less than or equal to 12 months.

- Doubtful Assets: - An asset which remain as NPAs for more than 12 months.

- Loss of Asset: - An Asset where loss is identified by the bank or RBI. Asset whose value is uncollectible, but there may be little value remaining in it.

\section{Major Causes of NPAs.}

\section{External Factors}

- Ineffective Recovery Tribunal

- Natural Calamities

- Poor Industrial Growth

- Willful defaults

- Changes made in the Government Policies.

\section{Internal Factors}

- Poor lending process

- Insufficient technology

- Poor Credit Appraisal System

- Inefficient Management. 


\section{LITERATURE REVIEW}

Joseph and Prakash (2014) this paper deals with the comparative analysis of advances \& NonPerforming Assets of Public \& Private sector banks. 5 years data from the year 2008-2013 has been used for analyzing. It was observed that Public sector banks are having more NPAs than Private sector banks. Secondary Data was used for the Research Purpose.

Chaudhary and Sharma (2011) the Paper focus on comparing NPA data of Public \& Private sector banks. The trend of NPA also have been studied and it was observed that, Public sector banks are unable to compete with private sector banks and needs to improve its performance in Management Information system and also there is a larger need of Imparting training to employees of Public sector banks to make them competitive in comparison with private sector bank employees.

Das and Dutta (2014) the study is done on comparing the NPAs of Public sector banks only. 26 public sector bank data on NPA was used. The comparison was done between SBI Associates and other Public Sector banks. Using the Anova test it was found that there is no significant difference in NPAs of SBI Associates and other Public sector banks.

Kaur and Saddy (2011) the paper mainly focused on understanding the concept of NPA \& factors contributing towards NPA. It also studies how NPA affect banking operations.

Mittal and Suneja (2017) the paper mainly examine the level of NPAs in the Indian banking sector and then analyzing the causes for Increasing NPAs. The study also concludes that the magnitude of NPA in Public sector banks is more than Private sector banks.

Miyan (2017) comparative analysis of selected Private and Public sector bank has been done on various performance parameters such as GNPA, ROA, and NNPA. 5 years data was use for analysis from 2011-2016. It was found that Performance of PSU banks is way behind the private sector banks. $\mathrm{T}$ - Test was used to find the significant difference.

Kumar et al. (2021) the study examines the impact of NPA on Profitability of banks. Only 2 banks HDFC \& SBI were used for comparison. It was found that Increase in the provisions for NPA declines the profitability of banks. It was also found that If NPAs are reduced then the Public sector banks could have a higher profitability.

Singh (2013) the magnitude of NPA is comparatively higher in public sectors banks than private sector banks. To improve the efficiency and profitability of banks the NPA need to be reduced and controlled.

Das and Dutta (2014) the study is done on comparing the NPAs of Public sector banks only. 26 public sector bank data on NPA was used. The comparison was done between SBI Associates and other Public Sector banks. Using the Anova test it was found that there is no significant difference in NPAs of SBI Associates and other Public sector banks.

Kaur and Saddy (2011) the paper mainly focused on understanding the concept of NPA \& factors contributing towards NPA. It also studies how NPA affect banking operations.

Mittal and Suneja (2017) the The paper mainly examine the level of NPAs in the Indian banking sector and then analyzing the causes for Increasing NPAs. The study also concludes that the magnitude of NPA in Public sector banks is more than Private sector banks.

Miyan (2017) comparative analysis of selected Private and Public sector bank has been done on various performance parameters such as GNPA, ROA, and NNPA. 5 years data was use for analysis from 2011-2016. It was found that Performance of PSU banks is way behind the private sector banks. $\mathrm{T}$ - Test was used to find the significant difference.

Boddu (2019) this study compares the Loans and Advances, NPAs of both public and private sector banks in India to explore the preventive measures to control the rising NPAs. Suitable preventive measures help banks to decrease the level of NPAs in India. A lower level of NPAs helps the banks in consolidating their position, increasing confidence to depositors and increasing market share of the banks.

Kumar et al. (2021) the study examines the impact of NPA on Profitability of banks. Only 2 banks HDFC \& SBI were used for comparison. It was found that Increase in the provisions for NPA 
declines the profitability of banks. It was also found that If NPAs are reduced then the Public sector banks could have a higher profitability.

Sahoo and Majhi (2020) the Paper analyze the recovery mechanism of NPAs with its three important wings i.e. recovery through Lok Adalat, Debt Recovery Tribunals (DRTs) and Securitization and Reconstruction of Financial Assets and Enforcement of Securities Interest Act (SARFASEI Act) and its impact on NPA.

\section{OBJECTIVES OF THE STUDY}

- To Ascertain the Trends in the Level of NPAs

- To know the Position of Private and Public sector banks in respect of NPAs of last 10 years.

- To compare the Level of NPAs of Selected Private \& Public sector banks in India.

- To suggest few measures to improve the level of NPAs of banks.

\section{RESEARCH METHODOLOGY}

As per the literature review it has been observed that the present study mainly focus on NPAs comparison of Public sector banks and Private sector banks. My study also focus on comparison of NPA level of Private and Public sector banks. Only selected prominent banks from each Private \& Public sector is taken for the study. Last 10 years data has been used for the meaningful study on NPAs. The secondary data has been used for analysis which is mainly taken from authentic sources such as RBI Publications etc. The data has been analyzed in tabular form, Trend analysis and ANOVA test has been used to find out significant difference.

\section{DATA ANALYSIS}

Table 1. Gross Non-performing Assets percentage to Gross Advances of the Private sector banks for the year 2011-12 to $2020-21$

\begin{tabular}{|c|c|c|c|c|c|c|c|c|c|}
\hline \multirow[b]{2}{*}{ Year } & \multicolumn{3}{|l|}{ HDFC } & \multicolumn{3}{|l|}{ ICICI } & \multicolumn{3}{|l|}{ AXIS } \\
\hline & $\begin{array}{l}\text { Gross } \\
\text { NPA }^{1}\end{array}$ & $\begin{array}{l}\text { Gross } \\
\text { Advances }^{2}\end{array}$ & $\begin{array}{l}\text { Gross } \\
\text { NPA to } \\
\text { Gross } \\
\text { Advances } \\
\text { percentage }\end{array}$ & $\begin{array}{l}\text { Gross } \\
\text { NPA }\end{array}$ & $\begin{array}{l}\text { Gross } \\
\text { Advances }\end{array}$ & $\begin{array}{l}\text { Gross } \\
\text { NPA to } \\
\text { Gross } \\
\text { Advances } \\
\text { percentage }\end{array}$ & $\begin{array}{l}\text { Gross } \\
\text { NPA }\end{array}$ & $\begin{array}{l}\text { Gross } \\
\text { Advances }\end{array}$ & $\begin{array}{l}\text { Gross } \\
\text { NPA to } \\
\text { Gross } \\
\text { Advances } \\
\text { percentage }\end{array}$ \\
\hline 2020 & 12559.38 & 1002726.8 & 1.25 & 40829.09 & 676290.3 & 6.04 & 26604.1 & 588797.7 & 4.52 \\
\hline 2019 & 11135.91 & 827334.92 & 1.35 & 45676.04 & 618985.2 & 7.38 & 27146.45 & 511096.4 & 5.31 \\
\hline 2018 & 8506.87 & 664254.34 & 1.28 & 53240.18 & 537945.1 & 9.9 & 30876.32 & 454550.9 & 6.79 \\
\hline 2017 & 5825.88 & 558566.64 & 1.04 & 42159.38 & 482460.4 & 8.74 & 20045.65 & 384723.4 & 5.21 \\
\hline 2016 & 4297.6 & 467579.38 & 0.92 & 26221.25 & 450182.6 & 5.82 & 5848.48 & 342312 & 1.71 \\
\hline 2015 & 3265.81 & 367887.84 & 0.89 & 15094.69 & 398962 & 3.78 & 3866.88 & 284008.7 & 1.36 \\
\hline 2014 & 2775.37 & 304963.21 & 0.91 & 10505.84 & 347211.5 & 3.03 & 3001.42 & 232498.8 & 1.29 \\
\hline 2013 & 2048.06 & 241306.07 & 0.85 & 9607.75 & 298416.4 & 3.22 & 2371.41 & 198900.7 & 1.19 \\
\hline 2012 & 1814.9 & 190968.9 & 0.95 & 9292.6 & 192333.8 & 4.83 & 1720.2 & 145904.9 & 1.18 \\
\hline 2011 & 1660.32 & 156705.26 & 1.06 & 9815.96 & 169181.8 & 5.8 & 1586.99 & 124119.8 & 1.28 \\
\hline
\end{tabular}

Source: RBI Reports

\section{Observations}

- Gross Advances of HDFC Bank is comparatively more than ICICI \& Axis bank, Whereas Gross Advances of ICICI bank are comparatively more than that of Axis Bank.

${ }^{1}$ All outstanding loans and advances including advances for which refinance has been received but excluding rediscounted bills, and advances written off at Head Office level.

2 Sum of all loans given by the bank defaulted by the borrowers. 
- Gross NPAs of HDFC Bank are comparatively Low than that of than ICICI \& Axis bank, whereas ICICI NPA are highest in comparison of other two banks.

- All these bank have the higher NPAs for the year $2019 \& 2020$ mainly due to corona pandemic.

- All the Banks have seen decrease in NPAs in the year 2020 in comparison to the year 2019.

- The financial position of HDFC in terms of Gross advances and NPAs is far better than other two banks.

Table 2. Gross Non-performing Assets percentage to Gross Advances of the Public Sector Banks for the year 2011-12 to 2020-21

\begin{tabular}{|c|c|c|c|c|c|c|c|c|c|}
\hline \multirow[b]{2}{*}{ Year } & \multicolumn{3}{|l|}{ SBI } & \multicolumn{3}{|l|}{ BOB } & \multicolumn{3}{|l|}{ PNB } \\
\hline & $\begin{array}{l}\text { Gross } \\
\text { NPA }\end{array}$ & $\begin{array}{l}\text { Gross } \\
\text { Advances }\end{array}$ & $\begin{array}{l}\text { Gross } \\
\text { NPA to } \\
\text { Gross } \\
\text { Advances } \\
\text { percentage }\end{array}$ & $\begin{array}{l}\text { Gross } \\
\text { NPA }\end{array}$ & $\begin{array}{l}\text { Gross } \\
\text { Advances }\end{array}$ & $\begin{array}{l}\text { Gross } \\
\text { NPA to } \\
\text { Gross } \\
\text { Advances } \\
\text { percentage }\end{array}$ & $\begin{array}{l}\text { Gross } \\
\text { NPA }\end{array}$ & $\begin{array}{l}\text { Gross } \\
\text { Advances }\end{array}$ & $\begin{array}{l}\text { Gross } \\
\text { NPA to } \\
\text { Gross } \\
\text { Advances } \\
\text { percentage }\end{array}$ \\
\hline 2020 & 149091.85 & 2422844.77 & 6.15 & 69381.43 & 738096.45 & 9.40 & 73478.76 & 516928.83 & 14.21 \\
\hline 2019 & 172750.36 & 2293454.12 & 7.53 & 48232.77 & 501706.39 & 9.61 & 78472.70 & 506194.30 & 15.50 \\
\hline 2018 & 223427.46 & 2048387.31 & 10.91 & 56480.39 & 460744.36 & 12.26 & 86620.05 & 471296.60 & 18.38 \\
\hline 2017 & 112342.99 & 1627273.00 & 6.90 & 42718.71 & 408510.92 & 10.46 & 55370.44 & 441751.36 & 12.53 \\
\hline 2016 & 98172.80 & 1509499.82 & 6.50 & 40521.04 & 405517.24 & 9.99 & 55818.33 & 432775.04 & 12.90 \\
\hline 2015 & 56725.33 & 1335423.71 & 4.25 & 16261.45 & 437280.38 & 3.72 & 25694.86 & 392422.15 & 6.55 \\
\hline 2014 & 61605.35 & 1245122.44 & 4.95 & 11875.90 & 403699.43 & 2.94 & 18880.06 & 359645.78 & 5.25 \\
\hline 2013 & 51189.39 & 1078557.11 & 4.75 & 7982.58 & 332811.32 & 2.40 & 13465.79 & 315244.03 & 4.27 \\
\hline 2012 & 37156.00 & 757888.60 & 4.90 & 3881.80 & 205453.60 & 1.89 & 8689.90 & 276107.70 & 3.15 \\
\hline 2011 & 23073.52 & 662444.06 & 3.48 & 2786.23 & 171801.48 & 1.62 & 4379.39 & 243998.78 & 1.79 \\
\hline
\end{tabular}

Source: RBI Reports

- Gross Advances of SBI Bank is comparatively more than Bank of Baroda \& Punjab National Bank.

- Gross NPAs of SBI Bank are comparatively Low than that of than Punjab National Bank \& Bank of Baroda, whereas Punjab National Banks NPA are highest in comparison of other two banks.

- Since 2016 there is a considerable rise in the Gross NPAs of all the above banks.

- The financial position of SBI Bank in terms of Gross advances and NPAs is comparatively better than other two banks.

\section{Gross NPAs of Public Sector Banks}

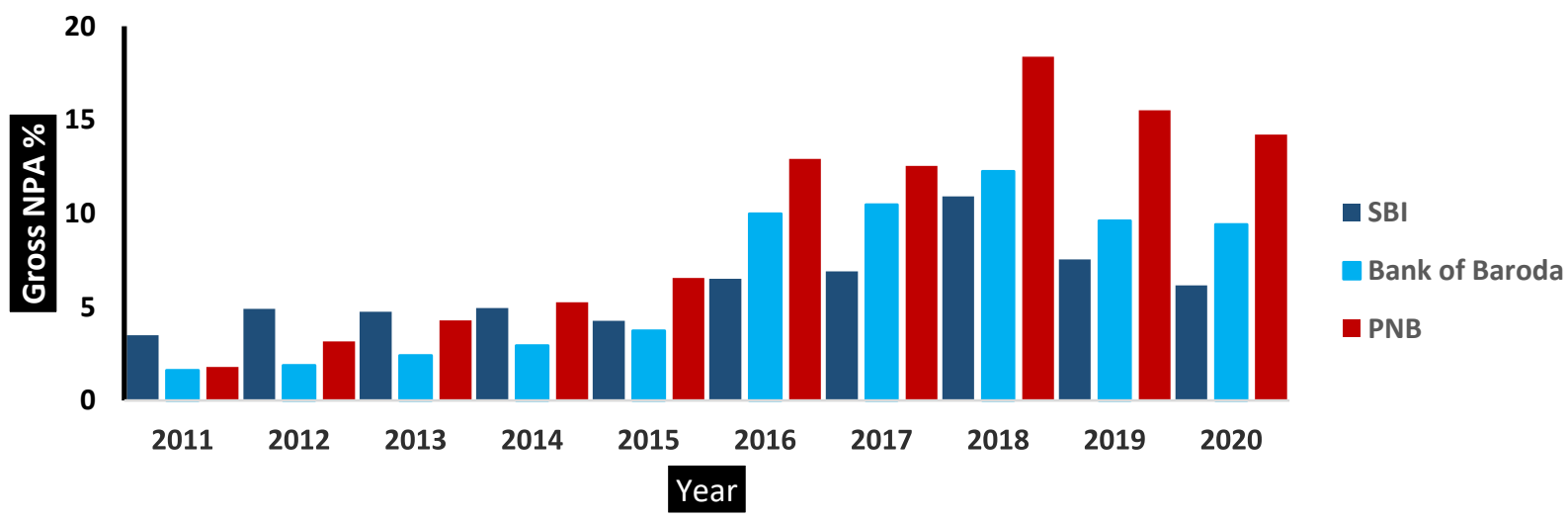

Figure 1. Gross NPAs of Public Sector Banks Source: RBI Reports 
- There is Considerable rise in the level of NPAs of all the above banks since 2016.

- Gross NPAs of Punjab National Bank has reached the highest to level of around $18 \%$ in the year 2018.

- Since 2018 Slight decline in the Gross NPAs percentage could be seen in all the above banks.

\section{Gross NPAs of Private Banks}

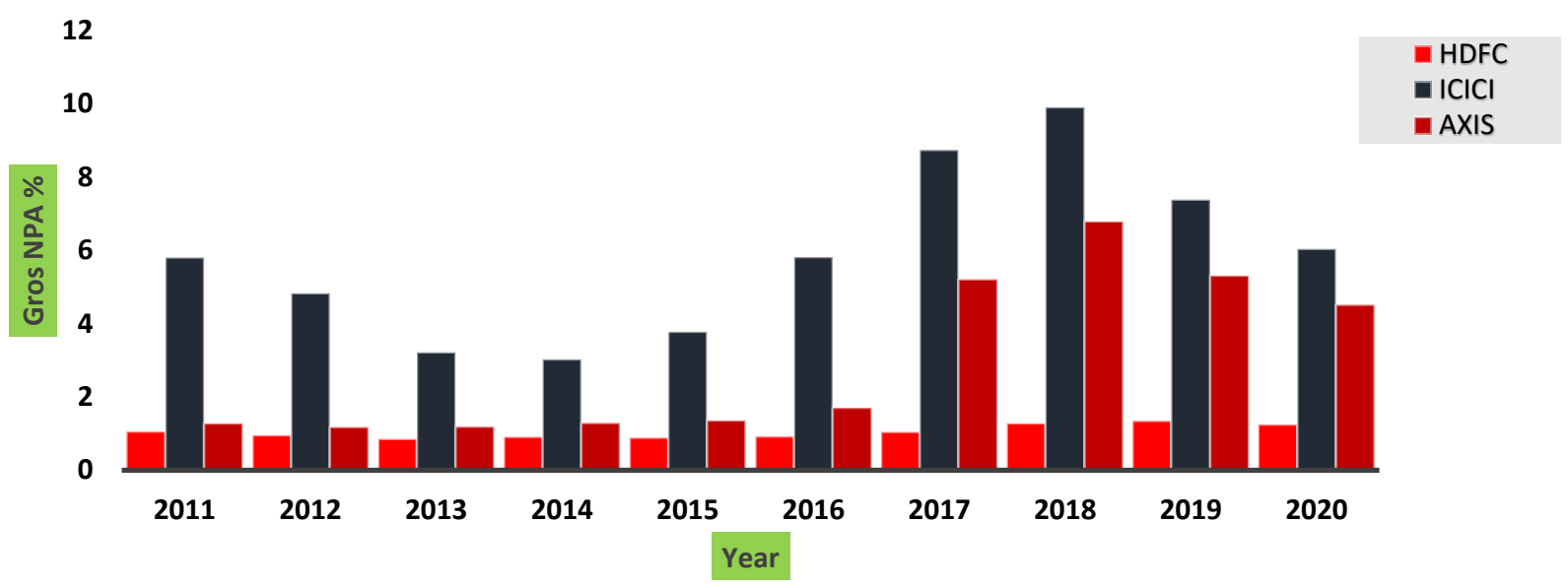

Figure 2. Gross NPAs of Private Banks

Source: RBI Reports

- There is Considerable rise in the level of NPAs of all the above banks since 2016.

- Gross NPAs of ICICI Bank has reached the highest to level of around $10 \%$ in the year 2018.

- Since 2018 Slight decline in the Gross NPAs percentage could be seen in all the above banks.

- Gross NPAs of HDFC Banks is more or less stable since 2011 to 2020.

\section{Gross NPA \% of Public sector Banks Trend upto 2025}
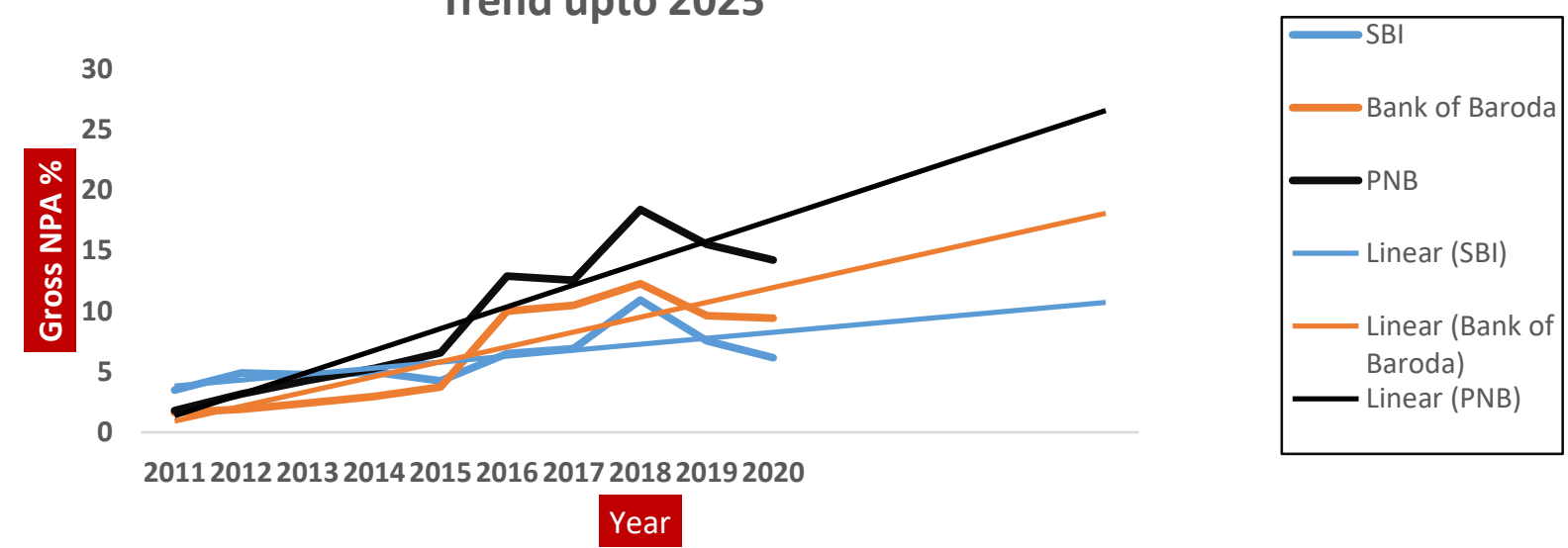

Year

Figure 3. Gross NPA \% of Public sector Banks Trend up to 2025 Source: RBI Reports

- Up to the year 2025 an upward trend could be seen of the NPAs of PNB and BOB, whereas SBI bank could be seen a flat level of NPAs till the year 2025 
Gross NPA \% of Private Banks \& Trend Analysis upto 2025

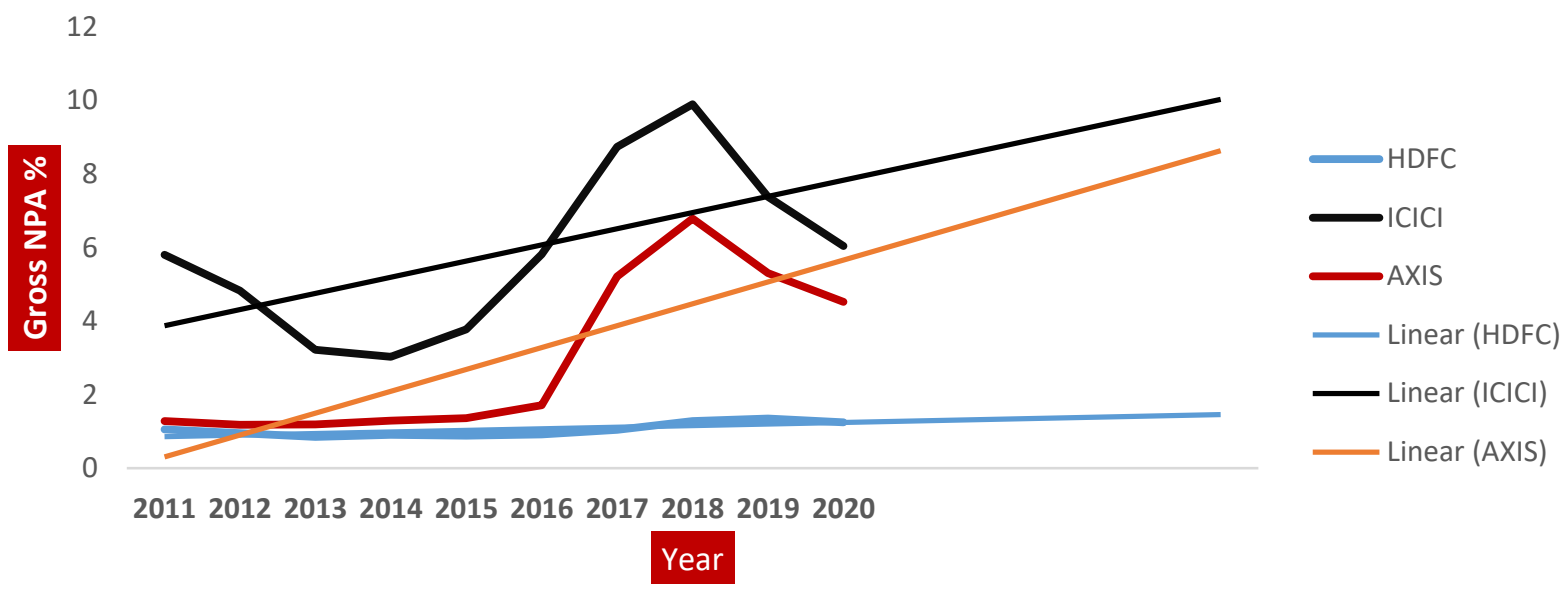

Figure 4. Gross NPA \% of Private Banks \& Trend Analysis up to 2025

Source: RBI Reports

- Up to the year 2025 an upward trend could be seen in the level of NPAs of ICICI and Axis bank, whereas level of NPAs of HDFC Bank are likely to remain stable until upcoming year 2025.

\section{Gross NPAs of Public \& Private banks}

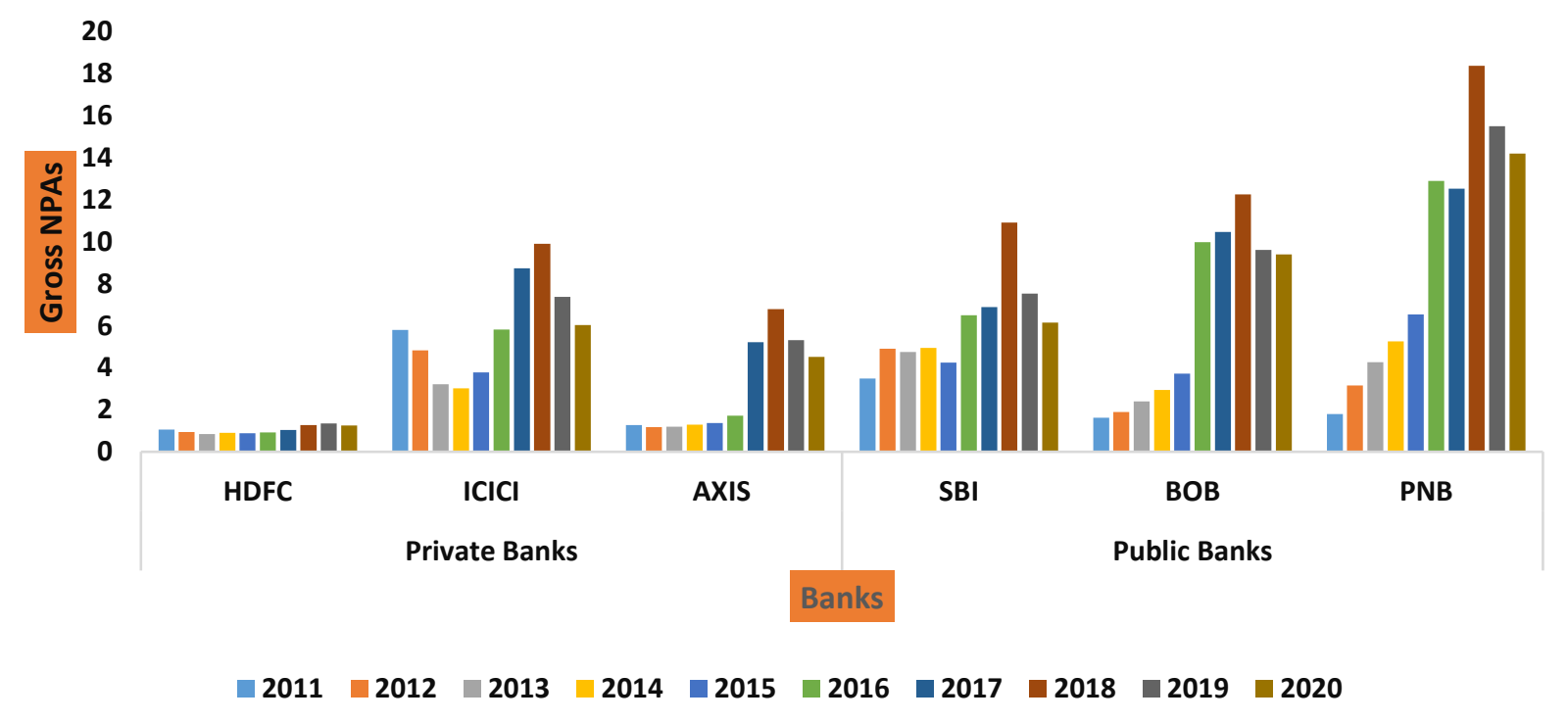

Figure 5. Gross NPAs of Public \& Private banks Source: RBI Reports

\section{Observations}

- In Private Banks above, HDFC NPAs are stable throughout the years. NPAs of ICICI bank are quite high than HDFC \& AXIS Bank.

- In Public sector banks above, NPAs of Punjab National Bank is higher than other two banks SBI \& BOB. 
- All the banks whether Private or Public sector banks could see increasing trend in the level of NPAs since the year 2016 except HDFC Bank whose Level of NPAs is stable throughout the periods.

Table 3. Performance of Public sector and Private sector banks.

\begin{tabular}{|l|l|l|l|l|l|l|}
\hline & \multicolumn{5}{l|}{ Private Banks } & \multicolumn{3}{l|}{ Public Banks } \\
\hline Year & HDFC Bank & ICICI Bank & $\begin{array}{l}\text { Axis } \\
\text { Bank }\end{array}$ & SBI & $\begin{array}{l}\text { Bank of } \\
\text { Baroda }\end{array}$ & $\begin{array}{l}\text { Punjab National } \\
\text { bank }\end{array}$ \\
\hline 2011 & 1.06 & 5.8 & 1.28 & 3.48 & 1.62 & 1.79 \\
\hline 2012 & 0.95 & 4.83 & 1.18 & 4.9 & 1.89 & 3.15 \\
\hline 2013 & 0.85 & 3.22 & 1.19 & 4.75 & 2.4 & 4.27 \\
\hline 2014 & 0.91 & 3.03 & 1.29 & 4.95 & 2.94 & 5.25 \\
\hline 2015 & 0.89 & 3.78 & 1.36 & 4.25 & 3.72 & 6.55 \\
\hline 2016 & 0.92 & 5.82 & 1.71 & 6.5 & 9.99 & 12.9 \\
\hline 2017 & 1.04 & 8.74 & 5.21 & 6.9 & 10.46 & 12.53 \\
\hline 2018 & 1.28 & 9.9 & 6.79 & 10.91 & 12.26 & 18.38 \\
\hline 2019 & 1.35 & 7.38 & 5.31 & 7.53 & 9.61 & 15.5 \\
\hline 2020 & 1.25 & 6.04 & 4.52 & 6.15 & 9.4 & 14.21 \\
\hline
\end{tabular}

\section{Observation}

- The performance of Public sector banks is very poor in comparison of Private sector Bank.

- HDFC is a top performer in Private sector banks whereas SBI is the top performer in Public sector banks.

- NPA level of Punjab National Bank are very serious in comparison of all other banks.

\section{T-Test Analysis}

A t-test is a type of inferential statistic used to determine if there is a significant difference between the means of two groups, which may be related in certain features. A t-test is used as a hypothesis testing tool, which allows testing of an assumption applicable to a population.

\section{Hypothesis}

Ho: There is no significant difference in the average values of the selected Private and Public sector banks.

$\mathrm{H}_{1}$ : There is significant difference in the average values of the selected Private and Public sector banks.

Table 4. Findings of T-test Analysis

\begin{tabular}{|l|l|l|}
\hline \multicolumn{2}{|l|}{ t-Test: Two-Sample Assuming Unequal Variances } \\
\hline & & \\
\hline & Variable 1 & Variable 2 \\
\hline Mean & 3.296 & 7.304666667 \\
\hline Variance & 2.271337778 & 15.95755605 \\
\hline Observations & 10 & 10 \\
\hline Hypothesized Mean Difference & 0 & \\
\hline df & 12 & \\
\hline t Stat & -2.969065558 & \\
\hline $\mathrm{P}(\mathrm{T}<=\mathrm{t})$ one-tail & 0.005860761 & \\
\hline
\end{tabular}




\begin{tabular}{|l|l|l|}
\hline $\mathrm{t}$ Critical one-tail & 1.782287556 & \\
\hline $\mathrm{P}(\mathrm{T}<\mathrm{t})$ two-tail & 0.011721522 & \\
\hline $\mathrm{t}$ Critical two-tail & 2.17881283 & \\
\hline
\end{tabular}

As $\mathrm{P}$ value is less than 0.05 it can be interpreted that Ho will be rejected and $\mathrm{H} 1$ would be accepted as there is a significant difference between the Average values of NPAs of Selected Public \& Private sector banks.

\section{Measures to Reduce NPAs of the Banks}

- Conducting Credible Credit appraisal of the company before giving loan.

- Continuously assessing the financial position of the company after giving Loan to avoid further bankruptcy and take timely action

- Selling off NPAs

- Use of Sarfaesi act, 2002

- Use of Insolvency Bankruptcy Code, 2016

\section{Importance of Insolvency \& Bankruptcy Code, 2016 in Recovery of NPAs of the Financial Institutions}

Insolvency \& Bankruptcy Code, 2016 was introduced to resolve the claims which involved Insolvent companies. Although many other law were present in India to deal with the insolvency problem such as Sarfaesi Act, 2002, Debt Recovery Tribunals and Lok adalats. The average recovery rate after enactment of IBC.2016 has increased to around 45\%. The average recovery time has also been decreased dramatically from 4 years earlier to this act. Insolvency \& Bankruptcy code has remarkably help in speedy recovery of loans on the basis of which Indian ranking in "Ease of Doing Business" 2020 Report of the World Bank has improved to $63^{\text {rd }}$ Position from $142^{\text {nd }}$ Position prior to the Introduction of this act.

\section{FINDINGS}

- The study makes it clear that all the above banks both private and public sector banks are facing serious problem of NPAs.

- Rising level of NPAs are impacting the Profitability and Liquidity of these banks.

- Condition of Public sector banks is very poor due to Rising NPAs.

- Performance of Private Banks is better than Public sector Banks in case of NPAs.

- HDFC Bank is best performer when it comes to NPAs. The level of NPAs is stable throughout the years.

\section{SUGGESTIONS}

- Evaluate CIBIL score of the borrower before giving any loan.

- Circulating Information of Defaulters in the Society.

- Continuously assessing the financial position by the lender of the borrower for timely recovery or avoiding huge losses.

- Using the speedy dispute settlement mechanism such as Insolvency \& Bankruptcy Code, 2016 for the recovery of bad Loans.

- Lending more to the Growing Sectors in the economy.

\section{CONCLUSION}

The study makes it clear that all the above Private\& Public Sector banks are facing the problem of NPAs. NPAs are affecting the liquidity and Profitability of these banks. ICICI Bank has a very high rate of Gross NPAs in Private sector banks compared to other 2 private sector banks HDFC \& AXIS Bank. Punjab National Bank has the higher rate of NPAs in Public sector banks and Private Banks. The Performance of HDFC bank is far better than ICICI \& Axis Bank as NPA Percentage of HDFC is more 
or less stable since last 10 years. Rising NPAs since last 5 years is a matter of concern for Indian banking system and also Indian financial system. It is equally important to take necessary steps by the banks and at government level to bring the NPAs down to restore the confidence in the banks. These banks should more focused on providing Quality Loan as "Prevention is always better than Cure" yes recent steps taken by government in respect of Insolvency code has got some relief to the banking sector to get fast recovery of loans but this mechanism of recovery of loans is post mortem and cannot enhance the economy, Ultimately giving Quality Loans is essential for the development of the economy and meeting its need.

\section{FUTURE SCOPE OF THE STUDY}

- The Research can be extended to other private and public sector banks.

- Foreign banks can also be included in comparison of level of NPAs.

- Many Variables other than NPAs can be used for meaningful comparison between banks such as Capital Adequacy Ratio, Liquidity Ratio, Profitability Ratio, etc.

- Other statistical test could also be used to analyse the data.

Conceptualization: CMA Jayraj Javheri

\section{AUTHOR CONTRIBUTIONS}

Data Curation: CMA Jayraj Javheri

Formal Analysis: CMA Jayraj Javheri

Funding Acquisition: CMA Jayraj Javheri

Investigation: CMA Jayraj Javheri

Methodology: CMA Jayraj Javheri

Project Administration: CMA Jayraj Javheri

Resources: CMA Jayraj Javheri

Software: CMA Jayraj Javheri

Supervision: Ravindra Gawali

Validation: CMA Jayraj Javheri

Visualization: CMA Jayraj Javheri

Writing - Original Draft: CMA Jayraj Javheri

Writing - Review \& Editing: CMA Jayraj Javheri, Ravindra Gawali

\section{CONFLICT OF INTEREST STATEMENT}

The authors declare that they have no competing interests.

\section{ACKNOWLEDGEMENT}

All authors contributed equally to the conception and design of the study.

\section{REFERENCES}

Alamelumangai, R., \& Sudha, B. (2019). Recovery of NPAs through Debt Recovery Channels in Indian Banks-An Analysis. Restaurant Business, 15(8), 245-254.

Boddu, S. N. (2019). Prevention of NPAs: A Comparative Study on Indian Banks. International Journal of Scientific Research Publications, 9(1), 618-622.

Chaudhary, K., \& Sharma, M. (2011). Performance of Indian public sector banks and private sector banks: A comparative study. International journal of innovation, management and technology, 2(3), 249.

Das, S., \& Dutta, A. (2014). A Study on NPA of Public Sector Banks in India. 
Das, S. K., \& Uppal, K. (2021). NPAs and profitability in Indian banks: an empirical analysis. Future Business Journal, 7(1), 1-9.

Joseph, A. L., \& Prakash, M. (2014). A study on analyzing the trend of NPA level in private sector banks and public sector banks. International Journal of Scientific and Research Publications, 4(7), 1-9.

Kaur, H., \& Saddy, N. K. (2011). A Comparative study of non-performing assets of public and private sector banks. International Journal of Research in Commerce and Management, 2(9), 42-50.

Kumara, S. (2018). Study on NPAs of Banks in India. ZENITH International Journal of Business Economics \& Management Research, 8(3), 160-169.

Kumar, A., Jha S., \& Grover, S. (2021). Impact of Non-Performing Assets on Profitability: A Study of Selected Private and Public Sector Banks in India. The Empirical Economics Letters, 19 (Special Issue), 129-138.

Mittal, R. K., \& Suneja, D. (2017). The problem of rising non-performing assets in banking sector in India: comparative analysis of public and private sector banks. International Journal of Management, IT and Engineering, 7(7), 384-398.

Miyan, M. (2017). A Comparative Statistical Approach towards NPA of PSU and Private Sector Banks in India. International Journal of Advanced Research in Computer Science, 8(1), 46-52.

Sahoo, M. K., \& Majhi, M. (2020). The recovery management system of NPAs-A case study of commercial banks in India. Parishodh Journal, 9(3), 5065-5076.

Singh, A. (2013). Performance of non-performing assets (NPAs) in Indian Commercial Banks. International Journal of Marketing, Financial Services \& Management Research, 2(9), 86-94.

Wadhwa, R., Ramaswamy, M. K., \& Fin, S. M. (2020). Impact of NPA on Profitability of Banks. International Journal of Engineering Technology and Management Sciences, 4(3), 1-8.

\section{Copyrights}

Copyright for this article is retained by the author(s), with first publication rights granted to the journal. This is an open-access article distributed under the terms and conditions of the Creative Commons Attribution license (https://creativecommons.org/licenses/by/4.0). 